\section{DEVELOPMENT OF ISLAMIC EDUCATION IN PHILOSOPHY OF EXISTENTIALISM PERSPECTIVE}

\section{Jam'ah Abidin}

Islamic Eduation Teacher DPK Junior High School Babussalam

\section{Abstract}

Development of Islamic Education in Philosophy of Existentialism Perspective: Theories of human resource development in the context of existentialism really uphold the fundamental principles inherent in every individual. That's, in the development of human resources through the efforts of Islamic Education must provide guarantees of freedom (hurriyyah/liberalism) to all students subject to be imaginative and creative according to their talents and their irâdah (will). For this flow, just the way a subject so students can develop their potential, so they were able to become a man of independent, creative, innovative and dynamic. This guarantees certainly described in the overall of educational system, both in the context of the curriculum, the learning process and the learning environment.

Keywords: Development, Islamic Education and Philosophy of Existentialism.

\section{Introduction}

Existentialism (wuivdiyyah) as the school of philosophy known in the history of philosophy in the twentieth century $\mathrm{AD}$, although, actually in the epistemology of Ibnu Sina (H/980-1037 370-427 AD) has also seen the idea stating that the existence (wujûd) precedes the essence. Ibnu Arabi (11651240 AD) who formulate tashawmuf wahdat al-wujûd (the unity of existence)

${ }^{1}$ Muhmidayeli, Educational Pbilosophy, (Bandung: Refika Aditama, Cetakan I, Maret 2011), page 137. and tashawwuf wujûdiyyah (existence) by Hamzah Fanshuri (w.1620 AD) and his student, Shamsuddin Sumaterani (w.1630 AD). ${ }^{2}$

Existentially, human as historical beings are entities which still continue to proceed with all the limitations inherent in him. Acquisition of human truth as proven experience and observed in addition to the patterns of thought that are also tied to knowledge and methodological owned. ${ }^{3}$

Existentialist are philosophers that rebelled against most of the properties of traditional philosophy and modern society. Existentialism is a protest against the Greek rationalism, especially speculative view of man (human is spirit and it is the body) such as Plato (427-347 BC) and Hegel (1770-1831 AD) who saw man as a totality. The human soul has three elements according to Plato the spirit, passion and ratios. He supposes spirit as attractive white horse carriage with black horses (lust) controlled charioteer (ratio) which seeks to control cart's speed. ${ }^{4}$ Many wonders in this world, but there is nothing more magical than humans, said the ancient Greek philosopher, Sophocles (500 BC). ${ }^{5}$ Socrates (469-399 BC) states that real learning is to learn about the human who gave birth Socratic Method/learning frequently asked questions methods). ${ }^{6}$ Human is full of magical mystery. A mystery of human: Philosophical Synthesis of paradoxical creature, said Louis Leahy. ${ }^{7}$ Science has not been able to solve the problem once and only can near to it, especially through existentialism.

\section{Epistemology of Existentialism (Wujûdiyyah) In Islam}

${ }^{2}$ Azra, Azyumardi, Association of Muslim Scholars Networking and Nusantara Archipelago XVII and XVIII AD, (Bandung: Mizan, First Edition, September 1994), page 178.

${ }^{3}$ Mumidayeli, et.all, Paradigm Building of Islamic Education, (Pekanbaru: PPs UIN Suska Riau, 2007), page 5.

${ }^{4}$ Ahmad Tafsir, The Pbilosophy of Islamic Education, Integrity of Body, Soul and Heart, Making Human more Human, (Bandung: Remaja Rosdakarya, Third Edition, November 2008), page 10

${ }^{5}$ Onong Uchjana Effendy, Human Relation, (Bandung: Remadja Karya, First Edition, 1988), page 21.

${ }^{6}$ Ahmad Tafsir, op.cit., page 8.

${ }^{7}$ Louis Leahy, I'homme, ce Mystere, Pour Une Pbilosophie de I'homme, translated by Purnama Sidi, Mistery of Human: Synthesis of Pbilosophy About Paradoxes Creature, (Jakarta: Gramedia, Second Edition, June 1985). 
Ibn Sina (born in Afsyanah, Bukhara, 980-1037 AD) until the age of 10 years had memorized al-Qur 'an, ${ }^{8}$ doctors and renowned Islamic philosopher, ${ }^{9}$ known in the West as Avicenna (Avessina/Spanish), and fame in the West as doctors go beyond fame as a philosopher, so he was given the title of The Prince of physicians. In the Islamic world, he was known as al-Shaykh al-Tsani (the Supreme Leader of the philosopher), while alFarabi known in the Latin world with the name Alpharabius and in the Islamic world known as al-mu'allim al-Tsâni (Second Guru), meanwhile the al mu'allim al Awwal was Aristotle (384-322 BD). ${ }^{10}$

Philosophy of Ibn Sina contrary to the general opinion that the body of human desire for the soul. According to Ibn Sina whose desire is not the body to the soul, but the soul where fleshly desire contrary to the body. With the help of external senses and five senses, the soul, he asserted the human mind, increase of the potential becomes actual and mustafâd (acquisition). When there is a fetus that is ready to accept the soul, this is where God creates a soul that matches the fetus. As the founder of the philosophy of wujûd (existentialism) Muslims are al-Farabi (870-950 AD) and Ibn Sina (980-1037 AD), ${ }^{11}$ but a more comprehensive existentialism epistemology seems suggested by Ibn Sina described his wujûd through philosophy into three categories: mandatory al-wujud bidzatih (required there by itself), mumkin al-wujûd (there may be) and mustabil al-wujûd or mumtani (impossible exist). ${ }^{12}$ That would be impossible, because there can not be, no more under discussion. That must exist, never did exist in the past and will never be anything in the future. He was diving there. Existence has no beginning and has no time and also end. He continued there. There does not have a cause. That is Allah SWT. That may exist, never existed in the

${ }^{8}$ Busyairi Madjidi, Educational Concept of Muslim Philosopher, (Yogyakarta: al-Amin Press, First Edition, March 1997), page 46.

${ }^{9}$ Azyumardi Azra, chief editor, Islamic Encyclopaedia, Jilid 2, Jakarta: Ichtiar Baru van Hoeve, Fourth Edition, 1997), page 167

${ }^{10}$ Harun Nasution, Islam Observed in Its Aspects, Jakarta: Bulan Bintang, U.I.Press, Sixth Edition, 1986), page 49.

${ }^{11}$ Harun Nasution, Pbilosophy of Religion, (Jakarta: Bulan Bintang, Sixth Edition, 1987), page 57.

${ }^{12}$ Harun Nasution, (1919-1998 AD), editor Syaiful Muzani, Rational of Islam: Idea and Thoughts, (Bandung: Mizan, First Edition, Dzulhijjah 1415 H/May 1995 M), page 94.

\section{Existentialism Perspective}

past is not, then there is and there is no return in the future. The existence had beginning in time and also has an end. He begins from nothing and ends up with nothing (his body, but his spirit remains there). Existence has a cause. wujûd is humans.

Each of which there must have essence (mâhiyah/quiddity) in addition to the wujûd. Between wijûd and mâbiyah, wujûd is more importantly, because wujûd which makes mâhiyah into existence in reality. Mabiyah found only in the mind or intellect, while the wujûd contained in the real world (empiric), outside of the mind or intellect. Mumtani' is mabiyah which can not form in the real world like any other cosmos outside our cosmos (al-'alam). Mumkin is mahiyah that can have form and may also not have a form, such as the horse and the human animal, which may have its mahiyah form and may not. Mandatory is mahiyah inseparable from his form. Here mahiyah and form are one. Instead, he was called a form that must exist (Mandatory alWujûd/Necessary Being) is God. His shape is its Mahiyah and His shape is its mahiyah. The form of the cosmos that is dependent on Mandatory mumkin al-Wujûd is the cause for all the other form. ${ }^{13}$

Compared to the essence, to Ibn Sina, wijûd is more important. Essence can exist in the mind alone. Essence does not necessarily exist outside the mind. Otherwise there must be a wujûd beyond reason. Which are (a wujud/existence) is more important than who does not exist. In the perspective of Ibn Arabi (1165-1240 AD, born in Mrcia/Spain and died in Baghdad/Iraq), after being the fact that the creature was made and that he had a hunger for the divine that makes it, because it has only Mumkin nature (there may be and probably no), and thus its form depends on something else. Something else is where it rests to be something that essentially has a form that characterized of compulsory, standing and do not intend to others in his form, even in its essence was he who gave the form to be used. Thus, the nature of which has become mandatory, but the nature of this obligation depends on something else and not on him. ${ }^{14}$

${ }^{13}$ Harun Nanution, Philosophy of Religion, page 58

${ }^{14}$ Harun Nasution, Philosophy and Mystic in Islam, (Jakarta: Bulan Bintang, Second Edition, 1978), page 94. 
The Thought of Islamic education culminating in educational ideas put forward by Ibn Sina (980-1037 AD) and Imam al-Ghazali (1058-1111 $\mathrm{AD})$ in the development of human resources quality. Quality was formed through syakkilat (formed talent with the mastery of science so that it becomes a profession). In this regard for example for contemplation and meditation, Allah says in the Qur 'an Sura al-Isrâ/Banî Isrầil (The Son of Israel) verse 78-84 :

Meaning : Establish regular prayers, ${ }^{15}$ at the sun decline till the darkness of the night and the recital fo the qur an in morning prayer, for the recital of dawn is witnessed. ${ }^{16}$ And as for the night keep awake a part of it as, ${ }^{17}$ an additional prayer for thee, soon will thy Lord Raise thee to a station of prase and glory. ${ }^{18}$ Say $\mathrm{O}$ my Lord ! Let my entry be by the gate of truth and honour and likewise my exit by the gate of truth and honour, and grant me from thee and authority to aid (me). And say, trusth ahs (now) arrived and falsehood perished, for falsehood is (by its nature) bound to perish. We sent down (stage by stage) of the Qur'an that which is a healing and a mercy to those who believe, to the unjust it causes nothing but loss after loss. Yet

${ }^{15}$ The commentators understand here the command for the five daily canonical prayers, the four from the declination of the sun from the zenith to the fullest darkness fo the night and the early morning prayer, Fajr (Shubb), which is usually accompanied by a reading of the the Holy Qur'an. The four afternoon prayers are: Zubr, immediately after the sun begins to declines in the afternoon, $A s h r$, in the late afternoon, Maghrib, immediately after sunset, and 'Tsyâ, after the glow of sunset has disappeared and the full darkness of the night has set in. There is differentce of opinion as to the meaning of particular words and phrases, but none as to the general effect of the passage. The Presidency of Islamic Researchers, IFTA, Call and Guidence, The Holy Qur' an, English Translation of the Meanings and Commentary, (The Kingdom of Saudi Arabia: Mushhaf al-Madinah al-Nabawiyyah, 1410 $\mathrm{H})$, page 802.

${ }^{16}$ The morning prayer is specially singled out for separate mention, because the morning is a peaceful hour and special influence act on the soul awaking from the noght`s rest. Special testimony is borne to the prayers of this hour by the angelic host. Ibid.

${ }^{17}$ This is held to be addressed specially to the holy Prophet who usually prayed more than the five cannocial prayers. The tahajjud was a prayer after midnight, in the small watches of the morning. Ibid.

${ }^{18}$ To the Prophet was to be assigned in the Hereafter thew highest post of honour and Glory, the Maqâm Mabmûd, implying his excellence above all athor prophets. The immediate reference may be to the hope that the Makkan persecution will soon be over and the glorious work in Madinah will begin. Ibid.
Existentialism Perspective

when We bestow Our fevours on man, he turns away and becomes remote on his side (in stead of coming to Us), and when Evil seizes him he gives himself up to despair. That is, Say: Everyone acts according to his own disposition (syâkilatih), but your Lord knows best who it is that is best guide on the way. ${ }^{19}$

Syâkilatih said in the beginning according to Tafsîr al-Mishbâh (Quraish Shihab) is used to branch on the way. Thus it can be interpreted by the road or custom made by someone. Sayyid Qutb in his commentary Zhilâl fi al-Qur'an (In the Shade Under al-Qur 'an), syâkilatih understood in the sense of the way and tendencies. ${ }^{20}$ The verse indicates that every human being has a tendency, potential and traits that drive their activities, ${ }^{21}$ to become experts in their field. Hamka in his Tafsîr al-Az̧hâr said syâkilatih is interpreted according to talent. Parents who gave birth into the environment, education, social and colony are forming a syakilatih. ${ }^{22}$ According to Ibn Sina (980-1037 M= 57 years), philosopher, and educator shufi of Islam, not all professions are desired by the kids and it might be, but it is appropriate and in line with the temperament. Therefore, it is fitting children's education if they want to choose a job those parents and teachers must consider the nature of children, the desire to know and test their intelligence, and then they choose the appropriate profession. ${ }^{23}$ Imam alGhazali who studied the formation of typical behavior that causes it predates many of the psychologists who study behavior. In addition, Imam al-Ghazali concerned on the formation behavior as giving direction to the goal of Islam and humanity, he is in line with the spirit of Islam as a person who sees the totality of human whose activities combine formal worship and mundane. This charity stands on a reasonable basis in terms of

\footnotetext{
${ }^{19}$ Ibid., page 802-804.

${ }^{20}$ Sayyid Quthb, Fî Zhilâl al-Our ân, translated As'ad Yasîn, dkk., Under the Shading of al-Qur'an, (Jakarta: Gema Insani Press, Fourth Edition, October 2010, Volume 7), page

${ }^{21}$ Quraish Shihab, Tafsìr al-Mishbâh: Message, Impression and Harmonious of al-Qur'an (Jakarta: Lentera Hati, Fourth Edition, October 2011, Volume 7), page 179.

${ }^{22}$ Hamka, Tafsîr al-Ažhâr, (Singapura: Pustaka Nasional, Fifth, 2003, Volume 6), page 4.108.

${ }^{23}$ Busyairi Madjidi, op.cit., page 62, and Hasan Langgulung, Principles of Islamic Edution, (Jakarta: Pustaka al-Husna Baru, Fifth 5, September 2003), page 129.
} 280. 
individual and public welfare and human moral elevation. Instead, he discussed the activities of the soul as a common symptom. ${ }^{24}$

Development of human resources, especially in the Malay-Indonesian world through thought of Fanshuri Hamzah, that is tashawwuf wujudiyyah (d.1620 AD) and Shamsuddin Sumaterani (d.1630 AD), both of Aceh, mainly influenced by the thought of al-wabdat al-wujûd form of Ibn Arabi. According to his thought, God's form is absolute. Thus they called God as mandatory form that al-Qa im form themselves, while the universe (al-'alam al-kabîr/macro cosmos) and human (al'alam al-shaghîr/micro cosmos) is referred to as mumkin al-wujûd is a form that may be (relative), because of its form depending on the Absolute Being. Absolute being is the ultimate cause of all manifestation. ${ }^{25}$

Muslim philosophers and shufi, especially Ibn Sina (philosopher, educator, and shufi), Imam al- Ghazali (philosopher, educator, and shufi), Ibn Arabi (shufi and educator) and Hamzah Fanshuri (shufi and educator) sees man as a totality. The learners (human) able to perform a number of activities in order to maintain the continuity of the existence of life, with the totality of its potential. His activity described the unique shape and its dynamics as a creature of God toward al-Insân al-Kâmil (the perfect man) who has the power of creativity to do and prosperity of nature. Existence does not just passively exist, but actively participate and manage the universe well thought coloring history and civilization of mankind is active, creative and dynamic. ${ }^{26}$

Filsafalat form especially Ibn Sina, Imam al-Ghazali, Ibn Arabi and Hamzah Fanshuri led to the conclusion that form is more important than the essence, existence is more important than essence. Instead, the philosophy of existentialism, appeared XX century AD, had already been put forward by philosophers and shufi in Islam, especially Imam al-Ghazali,

${ }^{24} \mathrm{Utsman}, \mathrm{AK}$, al-Dirâsat al-Nafsizyyat 'inda al-Muslimîn wa al-Ghazalî Biwâjỉin Khâshsh, (Qâhirah: Mathba-'ah Wahbah, 1963), page 158, and Hasan Langgulung, Islamic Education in 21 Century, (Jakarta: Pustaka al-Husna Baru, Third Edition, Oktober 2003), page 38.

${ }^{25}$ Abdul Hadi WM, Hamzah Fanshuri, Essay of Tashawnf and Its Poems, (Bandung: Mizan, First Edition, July 1995), page 40.

${ }^{26}$ Samsul Nizar, The Essence of Human According to Islamic Education, Building Educational Pattern Humanly, (Pekanbaru: Suska Press, First Edition, September 2009), page 1.
Ibn Sina in the XI century AD, Ibn Arabi XIII century AD and Hamzah Fanshuri XVII century style that characterizes Islamic religious education.

\section{The Meaning of Existentialism (Wujûdiyyah)}

Existentialism is a rebellion against the impersonal nature (no personality) of the modern industrial age (the age of technology) as well as the uprising against the mass movement in contemporary times. Industrial societies tend to exploit human to machine. Instead the man in danger is becoming a tool (computer, internet and robots). Scientific only see the outside of human action and human interpreted only as a part of the physical process. Existentialism is also a protest against the fascist and communist movements. Fascists are adherents of the ideology or the ideology of fascism is the extreme nationalist groups expect authoritarian rule. ${ }^{27}$ While the communists are the ones who embrace the ideology of communism, which tends to destroy individuality within the collective. Ideology that embraces the teachings of Karl Marx (1818-1883 AD) German nationality, was first published his book in 1847, The poverty of Philosophy and in 1848 AD, with his best friend, Friedrich Engels, published the Communist Manifesto, the book finally be the world's reading and the end of his life published the first volume of Das Kapital book, the second and third volumes forwarded by his loyal friend, F.Engels. Mao Tse Tung (1893-1976 AD) influenced the teachings of Karl Marx and Lenin (1870-1924 AD) of Russia, led the Communist Party to power in China. In terms of the success of China under Mao Tse Tung was a change in the economic system from the capitalist system to a socialist system. Mao managed to stir a revolution not only economic and political, but also social revolution through projects Leap Forward in the late 1950s and the Great Proletarian Cultural Revolution (Farm) in the late 1960s. Lenin was the founder of communist in Russia, a staunch follower of Karl Marx and faithful, preceded Mao and emits strong influence on Mao Tse Tung. ${ }^{28}$

${ }^{27}$ Titus, Smith and Nolan, Living Issues in Philosophy, alih bahasa H.M.Rasyidi, Persoalan-Persoalan Filsafat, (Jakarta: Bulan Bintang, First Edition, 1984), page 382.

${ }^{28}$ Prima Pena Team, Great Dictionary Indonesian Language, Jakarta: Gitamedia Press, w.y), page 259 . 
Existentialism is the ideology or human-centered view of the individual who is responsible for the free volition without knowing what is right and wrong. ${ }^{29}$ Existentialism is a philosophy that sees all the symptoms stem from the existence. In general, the word existence means existence, but in the philosophy of existentialism expression of existence has a special meaning. Existence is the human way of being in the world. The way people are in a different world with the way its being objects. The objects are not aware of its existence, which is also located next to one another, without the relationship. Human being is together with the objects. Objects become meaningful because of the human and held by humans. In addition, the human being is together with fellow human beings. To distinguish between these two ways of existence in the philosophy of existentialism stated that these objects are, while human existence. Thus, only humans are coexisting.

The word comes from the word extension ex (out) and consistency (derived from the Latin verb sisto, meaning stand, put). ${ }^{30}$ Rather, the existence of the word is defined, as a self- standing human with out of him in order to live independently. Man realized that he was there. He can doubt everything, but one thing is for sure that he was there. He was referred to me. Everything around it is connected with her (my cell phone, my computer, my home, my future, my education, etc.). In the human world to determine the situation with his actions He experienced himself as a person. He was found with his personal as if out of himself and busied himself with what is outside himself. He took advantage of the objects around him. With his work that he finds himself. It stands as you to get out of himself and was busy with the outside world. Thus human existence their self, it called Dasein, of the word $d a$ (there) and sein (to be), so it means, to be there is in a place. People always put themselves in the midst of the world around him, so that he was involved in the natural surroundings and united with him. Nevertheless, humans are not the same as the world around it, is not the same with objects, because people are aware of its existence.

${ }^{29}$ Michael H.Hart, The 100, A Ranking fo the Most Influential Persons in History, translated by Mahbub Djunaidi, Seratus Tokoh Yang Paling Berpengaruh Dalam Sejarah, Jakarta: Pustaka Jaya, Eleventh Edition, 1989.

${ }^{30}$ Prima Pena Team, op.cit., page 242.
Existentialism Perspective

Thought Existentialism in Development of Human Resource Education

One of the main pillars of modern society is the easy access to science and technology as a logical consequence of the strenuous efforts of the scientists and technocrats in answering the problems that exist within the realms of reality. The emergence of science and technology is not something that has no consequence, because entity in direct contact with the essential elements of humanity. Existence development is highly dependent on the development of education, so that a serious appreciation of the existence of the self and the world is a necessity, if we are to create a civilized society and personality intact. ${ }^{31}$

Existentialism is a philosophical school of a technical nature, which is manifested in a variety of systems, which are different from one another. ${ }^{32}$ However, there is also the same characteristics, which makes the system can be labeled as a philosophy of existentialism is thought Soren Kierkegaard (1813-1855 AD), Friedrich Nietzsche (1844-1900 AD), Karl Jaspers (18831969 AD), Martin Heidegger (1889-1976 AD), Gabriel Marcel (1889-1973 AD) and Jean Paul Sartre (1905-1980 AD). According to Titus, Smith and Nolan existentialist has six main characters (Martin Heidegger put them into the philosophical school of phenomenology), ${ }^{33}$ whereas according to Aaron Hadiwijono it is last four (Martin Heidegger, Karl Jaspers, Gabriel Marcel and Jean Paul Sartre) prominent existentialist. In taxonomists, there are two main streams of research activity in general, inclusive of research in the social sciences and education which flow Positivist and phenomenology. Positivist Flow gave birth praxis research with quantitative approach, meanwhile phenomenology flow gave birth praxis research with a qualitative approach. ${ }^{34}$ Phenomenological research is inductive. Descriptive approach used is developed from the philosophy of phenomenology (study conducted by Multi perspective view). The focus of phenomenological

${ }^{31}$ Onong Uchjana Effendy, op.cit., page 25.

${ }^{32}$ Muhmidayeli, Theories of Human Resources Development, (Pekanbaru: PPs UIN Suska Riau and LSFK2P, 2007), page v.

${ }^{33}$ Muhmidayeli, Educational Pbilosophy, page 138

${ }^{34}$ Sudarwan Danim, Becoming Qualitative Researchers , (Bandung: Pustaka Setia, First Edition, December 2002 ), page 32. 
philosophy is an understanding of the totality of human existence. The purpose Phenomenological research is to explain the experiences of a person in life, inclusive interaction with other people. Phenomenology is a method and philosophy. As she spread method steps to be taken, so it is up to the pure phenomenon, which started from a subject (human) as well as the philosophy of consciousness and attempted to reach the field of pure consciousness and descriptions of everyday life. If this has been done will remain essential description or intuition of essence. ${ }^{35}$

Some thought that possessed characteristics of the existentialist thinkers include:

1. Principal motive is what is called the way of human existence is Only humans coexisting. Existence is the typical way humans are. The center of attention in humans. Therefore, it is humanistic.

2. Existence must be interpreted dynamically. Existence means actively create themselves, to exist means to do, to be, to plan. Every time people become more or less on the circumstances.

3. In the philosophy of existentialism humans are viewed as open (transparent). Human is a reality that has not been done and remains to be established. Intrinsically tied to the world surrounding man, especially to his fellow man.

4. Philosophy of existentialism applying pressure to the concrete experience, existential experience. Only this experience means different. Heidegger applying pressure to the death, which clouded everything. Marcel emphasis on religious experience and Jaspers emphasized the life several experience - wide as death, suffering, struggle and guilt. ${ }^{36}$

\section{Soren Kierkegaard (1813-1855 AD)}

Soren Kierkegaard is a Religious thinker of Denmark. He is regarded as the founder existentialism. He grew up in a family that characterized the religious spirit and emotions inside. At the University Copenhagen, he found Hegel's philosophy, but he disagreed and opposed it. He held that

${ }^{35}$ Titus, Smith and Nolan, op.cit., page 389

${ }^{36}$ Harun Hadiwijono, The Core of West Philosophy History 2, (Yogyakarta: Kanisius, Fifth Edition, 1989), page 149. abstract thinking by eliminating human personality because he is only thinking and emphasizes the sense and tend to ignore people thinking, beliefs and convictions. At that time he was also opposed to the Danish Lutheran church and attempt to make Christianity that makes sense. He always writes in the autobiography and the use of irony and paradox. He emphasized the gulf between God and man and between God and nature. He argues that the belief that contain the acceptance of the absurd (not unreasonable). Among his works is the either Or, The Sickness unto Death, and Fear and Trembling. He had a lot of influence in philosophy, literature and religious thought in the twentieth century. ${ }^{37}$

\section{Friedrich Nietzsche (1844-1900 AD)}

He was born in Prussia, Germany, was educated at the University of Bonn and Leipzig. He is proficient in the field of philological (tahqiq al nushûsh), ancient literature, philosopher and poet. He is the grandson of two Lutheran pastors and pastor of children from the same stream. His father died at a young age and he was raised by his mother, sister and grandmother and two unmarried aunts. He attacked Christianity, democracy, women's movement and socialism. He emphasizes strength, virility and power. With writing, God is death; he sought a leader among over man (those who can demonstrate a high morality). After teaching literature at the University of Busel ancient, Switzerland, for 10 years, he stopped because of health issue and spends uninterrupted time to write. In 1889, he had a thought disorder (mental breakdown) that he carried until his death. Among of his works are The Birth of Tragedy, The Four Meditation, Thus Spoke Zarasustra, Beyond God and Evil, Toward a Genealogy of Morals, and after his death published his work The Will to Power. ${ }^{38}$

\section{Karl Jaspers (1883-1969 AD)}

He was born in Germany, studied law and medicine, but after serving as professor of psychology - psychiatry 1913-1916 in Heidelberg as a private lecturer, 1916-1921 as an Ordinary psychology, then move his concern to philosophy. This occurred in 1919, when he wrote his book Die Psychologie der Weltanschaungen (Psychology views-view World, 1919). In

\footnotetext{
${ }^{37}$ Titus, Smith and Nolan, op.cit., page 387.

${ }^{38}$ Ibid., page 390.
} 
1921-1937, he served as professor of philosophy at Heidelberg. His most important work is to determine the system Philosophy (Philosophy, published in 1932). One of the investigations very deeply about Nietzsche was written by Karl Jaspers. Jaspers has great attention to the good life and soul decisions. His philosophy is a guide for sensible life and deserve, philosophy is a continuous effort to search, where to live, feel, decide, act and face the dangers can not be ignored. Jaspers was a matter of concern since a long time ago that is about being who after a period of Kierkegaard's Philosophy of Existence must be investigated.

\section{Martin Heidegger (1889-1976 AD)}

He was born in Baden, Germany, and has a major influence on some philosophers in Europe and South America. He received his doctorate in philosophy from the University of Freiburg where he studied and became an assistant to Edmund Husserl, 1859-1938 AD (originator of phenomenology). Has served as a professor of philosophy at the University of Marburg, but then returned to Feinberg to replace Husserl. With the emergence of the Nazi movement, he broke away from Husserl because Husserl was Jewish. In 1933, he became Rector of the University of Freiburg (first Rector appointed by the National Socialist movement). At his inauguration speech, he gave a talk entitled Role of the University in the New Reich, to emphasize the idea of the triumphant emergence of a new Germany. When he realized that he had been exploited by the Nazi, he immediately resigned as Rector (1834), but still teaching until retiring in 1957. His very impressive work is Being and Time and Introduction to Metaphysics. Most of his writing discusses issues such as what is being? Why is there sometbing rather than nothing at all ? So are the titles of human existence, anxiety, alienation and death. ${ }^{39}$

\section{Gabriel Marcel (1889-1973 AD)}

He was a French existentialist, the Roman Catholic religion, philosophy focused like Jaspers, to issue form. Appropriate theme for philosophy is predicament (difficult position) humans. He wanted to answer two major questions: who am I ? And what form it? Though he showed

${ }^{39}$ Ibid., page 391. little confidence the nature of metaphysical systems that consist a sense that thinking has to a level where it should stop, but he did not set avoids metaphysical issues. The idea is usually presented in an informal and not systematic, in his diary and hammy theatrics. Essay, the Mystery of Being (two volumes), is the most systematic. He argues that philosophy is driven by the quest for extraordinary sense of the urgent need and the sense of inner restlessness. Philosophy does not try to look at things in an objective manner and apart, as a philosopher should have to do with the fact that he lives in the middle. ${ }^{40}$

\section{Paul Sartre (1905-1980 AD)}

He was born in Paris, France and also studying in the city. He was famous through his novels, plays and short story writing. His work in the field of basic philosophy is being and Nothingness, a masterpiece that talk about nature, the forms of existence (being), and Existentialism and Humanism, a small book about humans. During World War II, he joined the French army and liberation movements. He was a leftist movement that advocates and defenders of human freedom. He stated that people who have no religious or backrest can not rely on external forces; humans must rely on their own strength. His books containing philosophy is Nausea, writing drama No Exit and The Flies and short stories about the psychology of death which includes The Wall. ${ }^{41}$

Existentialism emphasizes the uniqueness and existence of the first position, experience and awareness in the immediate. The principal of Insistence that or booster is to live and to be recognized as an individual. If the human person is recognized as such, he will acquire meaning in life. The most important place to ask for a man is a direct awareness and consciousness can not be loaded in the system or in the abstract. Abstract thinking tends to be impersonal and keep a person from concrete human sense and a sense of being in a human situation. Reality (form) is the existence of which there is in me and not in objects. Rather, it is the center of thought and meaning in the existence of a thinker. 
The existentialist's aside existence and essence. Existence means that the actual situation, which occurs in space of time, showing the existence of an object that is here and now. Means that the existence of the human soul or acknowledged the existence or his life. But for the group the existentialists, the verb to exist has a more positive meaning and richer than the verb to live. Sometimes people say about people who live empty and without meaning that he is not alive, he was just there. Group the existentialists changing words and said that the man was not there, he just lives. For them the existence of a life full of meaning, agile, aware, and growing responsibilities. The term essence is the opposite of existence is something that distinguishes between one object and another object style. Essence is to make the thing as it is or a publicly owned by a variety of objects.

Essence is common for some individuals and we can talk about the essence of the meaning, although there are no examples those things at a time. We distinguish between what is that thing? And that what is that this ? The first response is the essence, while the second is the existence. Things that I hold in my hand is a mobile phone and this phone, which I felt with my senses, there are (exist). If someone has understood the idea (the concept of) the essence of an object, he will be thinking about regardless of the existence. For Plato and other thinkers most humans have a concept of reality that is more than a man, Aristotle, for example, said that participation in the idea or form (form) or the essence of humanity, is what makes a person human. The existentialists reject Plato's view and stated that there are some things that can not be conceived that personal action to exist (personal act of existing). They assert that existence is a state of the first. $^{42}$

Jean Paul Sartre, writer and philosopher from France, followed Nietzsche in denying the existence of God, but the existentialist Sartre is the most reliable figures stating that existence comes before essence (existence before essence) is the common ground for existentialists. Humans have the freedom to establish him with the will and actions. Sartre divides human way of being in two areas, namely the phenomenon of life être en soi (being

${ }^{42}$ Ibid., page 395.

\section{Frcistentialism Perspective}

in it) and être pour soi (being for it). The first one was performed in a manner similar to the existing objects away without consciousness and without any meaning of life, such as plants and animals, while the second is a special way of being human in humans. Patterns in persons are indicated by the existence of the awareness that can make their life meaningful. Awareness will not appear in man in the absence of freedom. Therefore, the flow is highly emphasized freedom in the development of human resources. ${ }^{43}$ Whatever meaning was based on the meaning of the word freedom (burriyyah/liberalism) which clearly says it always focuses on the question of how a person acts in that select an existing reality without coercion and not the only option he choose and defined as actions that should do. If so, talk about freedom, can not be separated from the consciousness of doing that actually arise from the choice of subject. The Meaning is that if a person is said to have the freedom to act, someone not restricted, suppressed or forced to do it. ${ }^{44}$

Independence rather than something that must be proved or discussed, independence is a reality that must be experienced. Humans have enormous freedom that can be exploited if he could understand it. Independence will carry out the demands of the core character of the human soul and express the real and authentic. He faces the choices, decisions and assigns responsibility on all of it. Above all, people have to accept the responsibility of decision-making that has helped make it, as it does now. ${ }^{45}$ When associated with the philosophy of Alfred North Whitehead (1861-1947 AD), was a figure hard realism and criticized the traditional view of science that separates between matter and life, body and mind, nature and soul, substance and quality. Such an approach emptying nature of sensory quality and tend to breaking the ethic value, aesthetics and religion. Newton methodology led to success in the physical sciences but make nature without meaning and without value. Whitehead called the fallacy of misplaced abstraction concreteness. This happens when someone

${ }^{43}$ Ibid., page 384 .

${ }^{44}$ Muhmidayeli, Educational Philosophy, page 138

${ }^{45}$ Amril M, Akblak Tashawnf, (Pekanbaru: PPs UIN Suska Riau and LSFK2P, First Edition, 2007), page 92. 
noticed an aspect of the matter and considers it as a totality. ${ }^{46} \mathrm{He}$ is the originator of the philosophy that the human organism precedes through four stages:

Datum, processing, fulfillment and decisions. In the first stage, humans are at the stage of collecting entities that have actual past experience that the process will serve as initial data for the actual delivery of the new entity. In the second stage, humans are at the stage where treatment is a subject students are invited to experience first hand the process of occurrence of something. The third stage, in terms of the basic purpose of education is always associated with the existentialist position that wanted individuals capable of developing certain potential for him to perfection. The fourth stage, something real is not only present, but also that there was in the past and who will be there in the future. ${ }^{47}$

The purpose of education in the view of existentialism is to encourage each individual to be able to develop all their potential for self-fulfillment as well as provide supplies extensive and comprehensive experience in all forms of life. Student position in view of existentialism is as rational beings with free choice and responsibility or a commitment to the fulfillment of choice educational purposes. The state of curriculum in view of existentialism is that prime by liberal curriculum that is the foundation for human freedom. Freedom has rules. Therefore, education should be taught in schools to teach social respect (respect) the freedom for all.

In the perspective of the learning process of knowledge existentialism does not shed, but offered to establish the relationship between teachers with students as a dialogue. While the role of teachers to protect and preserve academic freedom. This stream looked no intensive thinking about the methods, but any method used should refer to the unique way to achieve happiness and good character (the formation of attitudes/affective).

Majority opinion of those who appear to think a bit emotional and small-minded that attitude is not to be taught as well as mathematics,

${ }^{46}$ Titus, Smith and Nolan, op.cit., page 386.

${ }^{47}$ Ibid., page 333 . 耳.istentialism Perspective

physics, sociology, anthropology, etc, but to be formed. Therefore, more appropriate to the field of affective teaching is not a term, but educational. Therefore, attitudes and values learning strategies geared to achieving educational goals that not only cognitive dimensions, but also the affective dimension (attitude) and psychomotor (behavioral), through a learning process that emphasizes learning activities of students as subjects.

Cognitive and psychomotor learning is different from the affective related to affective value that are difficult to measure, because it involves growing awareness of someone who internality. Within certain limits it can appear in affective behavioral incident, but his judgment to arrive at a conclusion that can be accounted requires precision, accuracy and continuity of observations and it is not easy to do, let alone assess changes in attitudes as a result of the learning process that teachers in schools. It is hard to conclude that the boy was a good gesture, for example, be seen from the language habits of courtesy, friendly, gentle, respectful and obedient as a result of the learning process that teachers do. Maybe that attitude is formed by habit in the family environment, and social environment.

Values of education stance are basically education. Attitude is a reflection of the values held. Love or hate attitude, one's sympathy or antipathy towards the object that it faces, will be greatly influenced by the level of understanding (cognitive aspect) of the object. Therefore, the level of reasoning (cognitive) objects to something and the ability to act against him (psychomotor) also determine a person's attitude towards the object in question, for example, a person may provide explanation (an explanation) from various angles that stealing is not good and is prohibited by norms any (cognitive aspect). Based on that knowledge, he did not like doing it (affective aspect). However, negative attitudes toward the new steal behavior we can see from the real action that although there is a chance to steal, he will not do it. And an assessment of the negative attitude toward stealing it more convincing that it does not steal the deed he had done, even though plenty of opportunities for that. ${ }^{48}$ Changes in attitude (attitude change) is highly dependent on the person's value system is considered the

${ }^{48}$ Muhmidayeli, Educational Philosophy, page 139. 
most correct and then the attitude that will control the behavior of the person (istiqamab). In this regard for example for contemplation and meditation, Allah says in the Qur an Sura Hâ Mîm al-Sajadah (Fushshilat) verses 30-36:

Its Meaning: In the case of those who say, Our Lord is Allah and further, ${ }^{49}$ stand straight and steadfast, the angels descend on them (from time to time), fear ye not (they suggest), nor grieve ! But receive the glad tidings fo the garden (of bliss), the which ye were promised! We are your protectors in this life and the Hereafter, therein shall ye have all that you shall desire, therein shall ye have all that ye ask for! A hospitable gift from One Off-Forgiving, Most Merciful! Who is better in speech, ${ }^{50}$ than one who calls (men) to Allah, works rightenousness and says, I am of those who bow in Islam ? Nor can goodness and evil be equal. Repel (evil) with what is better, than will he between whom and thee was hatred become as it were they friend and intimate! And no one will be granted such foodness except those who exercise patience and self-restraint, none but persons of the greatest good fortune. And if (at any time) an incitement to discord is made to thee by the Satan, seek refuge in Allah. He is the One who hears and knows All Things.

Istiqâmah (commitment) of a person against a particular value occurs through the formation of the tendency of a person's attitude toward an object, for example, if one is dealing with an object, it will show the

${ }^{49}$ The people who succeed to eternal life are those who recognise and understand the one and only eternal reality and further shape their probationary. Life firmly and steadfastly on the principles of that truth and reality. They will have their friends dan steadfastly on the principles of that truth and reality. They will have their friends dan
protectors in the good angels, in contrast to the evil ones, who will have no friendship, but only the reproaches of the Satan. The Presidency of Islamic Researchers, IFTA, Call and Guidence, The Holy Qur'an, English Translation of the Meanings and Commentary, (The Kingdom of Saudi Arabia: Mushhaf al-Madinah al-Nabawiyyah, 1410 H), page 1462.

${ }^{50}$ Ahsanu qaulâ (Better in speech), i.e., speaks better counsel, or is more worthy of being listened to. That his word reaches the highest mark of human speech is evidenced by three facts; (1) That he calls all to the truth of Allah, showing that his thought sre not centred on himself, (2) Every deed of his is rightenousness, showing that there is no divergence between his preaching and his conduct, and (3) He completely associates himself with the will of Allah, showinbg that he is the full imbodiment of Islam. What a fine description of the holy Prophet! Ibid., page 1463.

${ }^{51} \mathrm{Ibid}$., page 1462-1464. phenomenon of love or hate, sympathy or antipathy. Someone who is dealing with education as an object, then when he listened to and watched on television dialogue about education for example, it will show symptoms by following the dialogue pleasure it seriously until complete, and otherwise one phenomenon indicating antipathy toward education issues, it will be closed ear and move the program to a television channel of interest.

Value for someone is dynamic and not static (old-fashioned). Everyone will think something good (opinion change) according to the paradigm at the time. Therefore, the value system of a person can be nurtured and directed in such a way. If one considers the value of religion is above all else, the other values will depend on the value of religion. Thus, a person's attitude is highly dependent on the system which he considered the most correct values (attitude change) and then it's the attitude that will control the behavior of the person in the act (behavioral change), ${ }^{52}$ thus causing it to obey. There are four basic factors that constitute a person's adherence to certain values, namely:

a. Normative, usually compliance with legal norms. Compliance is contained in three forms, namely (1). Adherence to the norms or values itself, (2). Adherence is to the process without regard to the norm, (3). Compliance is with the expected outcome or purpose of the regulation.

b. Integrality is based on the awareness that compliance with rational considerations.

c. Phenomenal is compliance based on conscience or just lip service.

d. Hedonist is compliance based on self-interest (the passions). ${ }^{53}$

Of the four factors on which the compliance of each individual ( student) is of course expected that compliance is normative, because such compliance is compliance based on full awareness of the meaning and function of the value for themselves, regardless of whether it is advantageous to conduct himself or does not .

${ }^{52}$ Wina Sanjaya, Wina Sanjaya, Learning Strategy Oriented Standard of Educational Process, (Jakarta: Kencana, Fourth Edition, March 2009), page 272.

${ }^{53}$ Ibid., page 274. 
Development of human resources according to the time of the Renaissance Humanism philosophical schools (Aufklarung) and rationalism in the XVIII and XIX centuries $\mathrm{AD}$ and materialism and scientism XX and XXI century AD, almost cornering and discredit religion , inclusive most philosophers in the philosophy of existentialism, especially Sartre Nietszche and who consider God is death. Existentialism saw man as a totality. These schools mainly criticized the ideology of materialism and idealism that totalized human.

Philosophy of existentialism is applying pressure to the concrete experience, existential experience. This just means different experience, Heidegger applying pressure to the death, which clouded everything. Marcel emphasis on religious experience and Jaspers emphasized the life several of experience - wide as death, suffering, struggle and guilt.

Existentialism is metaphysics (nature of reality) view of the human person is not perfect and can be improved through self-realization by applying the principles and standards of personal development. Epistemological (nature of knowledge) looked at the data, and personally as an internal reference individual freedom to choose the best. Meanwhile, logic (the essence of reasoning) is for an understanding of the needs and internal motivation through self analysis and introspection. As for the axiological (value nature) existentialism view the standards and principles vary in each individual is free to choose and take. The nature of the good (ethics) by existentialism is a moral imperative for private interests without hurting others. While aesthetics (beauty nature) in view of existentialism determined individually in each person by himself. Finally as a way of life (life purpose) according to existentialism improve themselves through the standard liberal (burriyyah) by each individual to seek the perfection in life (al-insan al-kamil/the perfect human).

Development of human resources through Islamic education the world needs now is a modern education based on the existence of (a form of) human beings as taught primarily by shufi Muslim philosophers, especially Ibn Sina (form) and Ibn Arabi (Wabdat al-form) and Hamzah Fanshuri (wujudiyyab) is a human concept that has the power of thinking called reason ( ratio ) and the sense of the so-called heart (intuition). Sense

\section{5acistentialism Perspective}

developed through science education and a sense of power through the Islamic Education. Ideally, the system of Islamic education, religious education has the same position with the importance of science education. Both philosophically an essential and integral part of the Islamic education system.

\section{Conclusion}

Education is to change the attitude of the students. Education student's attitude is basically education educational value. Attitude is a reflection of the values held. Love or hate attitude, one's sympathy or antipathy towards the object that it faces, will be greatly influenced by the level of understanding (cognitive aspect) of the object. Rather, the level of reasoning (cognitive) objects to something and the ability to act against him (psychomotor) also determine a person's attitude towards the object in question, for example, a person may provide explanation (an explanation) from various angles that taking drugs and commit acts of corruption that is not good and prohibited by any norms (cognitive aspect). Based on that knowledge, he did not like doing it (affective aspect). However, negative attitudes toward drug consuming behavior and corruption and new can be seen from the real action that although there is an opportunity to do so, he will not do it. Assessment of the negative attitude toward the attitude is more convincing that it was not evil deed he ever did, despite many opportunities to perform. Thus, the pattern and attitude of Islamic Education means have to be implemented in life.

\section{Bibliography}

Azra, Azyumardi, Association of Muslim Scholars Networking and Nusantara Archipelago XVII and XVIII AD, Bandung: Mizan, First Edition, September 1994.

, chief editor, Islamic Encyclopaedia, Jilid 2, Jakarta: Ichtiar Baru van Hoeve, Fourth Edition, 1997.

Tashawnf Encyclopaedia, Bandung: Angaksa, First Edition, 2008.

Danim, Sudarwan, Becoming Qualitative Researcher, Bandung: Pustaka Setia, First Edition, December, 2002. 
Effendy, Onong Uchjana, Human Relation, Bandung: Remadja Karya, First Edition, 1988.

H.Hart, Michael, The 100, A Ranking fo the Most Influential Persons in History, translated by Mahbub Djunaidi, Seratus Tokoh Yang Paling Berpengaruh Dalam Sejarah, Jakarta: Pustaka Jaya, Eleventh Edition, 1989.

Hadi WM, Abdul, Hamzah Fanshuri, Essay of Tashawuf and Its Poems, Bandung: Mizan, First Edition, July 1995.

Hadiwojono, Harun, The Core of West Philosophy History 2, Yogyakarta: Kanisius, Fifth Edition, 1989.

Hamka, Tafsîr al-Az̧âr, Singapura: Pustaka Nasional, Fifth, 2003, Volume 6.

Langgulung, Hasan, Islamic Education in 21 Century, Jakarta: Pustaka al-Husna Baru, Third Edition, Oktober 2003

-, Principles of Islamic Edution, Jakarta: Pustaka al-Husna Baru, Fifth 5, September 2003.

Leahy, Louis, I'homme, ce Mystere, Pour Une Philosophie de I'homme, translated by Purnama Sidi, Mistery of Human: Synthesis Of Philosophy About Paradoxes Creature, Jakarta: Gramedia, Second Edition, June 1985.

M, Amril, Akhlak Tasawnf, Pekanbaru: PPs UIN Suska dan LSFK2P, First Edition, 2007.

Ethic and Education, Yogyakarta: LSFK2P, First Edition, November 2005.

Madjidi, Busyairi, Educational Concept of Muslim Philosopher, Yogyakarta: alAmin Press, First Edition, March 1997.

Muhmidayeli, et.al., Paradigm Building of Islamic Education, Pekanbaru: PPs UIN Suska Riau, 2007.

--, Theories of Human Resources Development, Pekanbaru: PPs UIN Suska Riau and LSFK2P, 2007. -, Educational Philosophy, Bandung: Refika Aditama, First Edition, March 2011.

-, The Thought of Ethic by Ibn Miskawaih and J.J.Rousseau: Comparative Study of Moral Philosophy, Pekanbaru : Susqa Press, First Edition, 2001.
Nasution, Harun, 1919-1998 M, editor Syaiful Muzani, Rational of Islam: Idea and Thoughts, Bandung: Mizan, First Edition, Dzulhijjah 1415 H/May 1995 M.

---, Philosophy of Religion, Jakarta: Bulan Bintang, Sixth Edition, 1987.

, Philosophy and Mystic in Islam, Jakarta: Bulan Bintang, Second Edition, 1978.

Islam Observed in Its Aspects, Jakarta: Bulan Bintang, U.I.Press, Sixth Edition, 1986.

Nizar, Samsul, The Essence of Human According to Islamic Education, Building Educational Pattern Humanly, Pekanbaru: Suska Press, First Edition, September 2009.

The Presidency of Islamic Researchers, IFTA, Call and Guidence, The Holy Quran, English Translation of the Meanings and Commentary, The Kingdom of Saudi Arabia: Mushhaf al-Madinah al-Nabawiyyah, $1410 \mathrm{H}$.

Prima Pena, Team, Great Dictionary Indonesian Language, Jakarta: Gitamedia Press, w.y.

Quthb, Sayyid, Fî Zhilâl al-Qur ân, translated As'ad Yasîn, dkk., Under the Shading of al-Quran, Jakarta: Gema Insani Press, Fourth Edition, October 2010, Volume 7.

Sanjaya, Wina, Learning Strategy Oriented Standard of Educational Process, Jakarta: Kencana, Fourth Edition, March 2009.

Shihab, Quraish, Tafsîr al-Mishbâh: Message, Impression and Harmonious of alQuran, Jakarta: Lentera Hati, Fourth Edition, October 2011, Volume 7.

Tafsir, Ahmad, The Philosophy of Islamic Education, Integrity of Body, Soul and Heart, Making Human more Human, Bandung: Remaja Rosdakarya, Third Edition, November 2008.

Titus, Smith dan Nolan, Living Issues in Philosophy, alih bahasa M.Rasyidi, Persoalan-Persoalan Filsafat, Jakarta: Bulan Bintang, First Edition, 1984.

Utsman, AK, al-Dirâsat al-Nafsiyyat 'inda al-Muslimîn wa al-Ghazalî Biwâjihin Khâshsh, Qâhirah: Mathba-'ah Wahbah, 1963. 